\title{
"Green grabbing," pastoralism and environmental dynamics in Northern Kenya. An assessment of conservation models and practices in Marsabit County
}

Benoit Hazard and Christine Adongo

\section{(2) OpenEdition}

\section{Journals}

Electronic version

URL: https://journals.openedition.org/eastafrica/291

DOI: 10.4000/eastafrica. 291

ISSN: 2790-1076

Publisher

IFRA - Institut Français de Recherche en Afrique

Printed version

Date of publication: 1 May 2015

Number of pages: $40-62$

ISSN: 2071-7245

\section{Electronic reference}

Benoit Hazard and Christine Adongo, "'Green grabbing," pastoralism and environmental dynamics in Northern Kenya. An assessment of conservation models and practices in Marsabit County", Les Cahiers d'Afrique de l'Est / The East African Review [Online], 50 | 2015, Online since 07 May 2019, connection on 11 October 2022. URL: http://journals.openedition.org/eastafrica/291 ; DOI: https:// doi.org/10.4000/eastafrica.291 


\title{
“Green grabbing", pastoralism and environmental dynamics in Northern Kenya. An assessment of conservation models and practices in Marsabit County.
}

\author{
Hazard Benoit ${ }^{1}$, Adongo Christine ${ }^{2}$
}

\begin{abstract}
In Northern Kenya, the history of protected areas reflects the debates that have shaped the world of conservation and environmental concerns. For a long time colonial assumptions about pastoralist uses of natural resources have been part of environmental policies and legitimized appropriation of nature. How does the implementation of natural resources management projects interact with pastoralists' natural heritage and their future economies in the context of socio-ecological transition? This paper questions the relations between conservation practices and the regional environmental dynamics of five protected areas in the broader Chalbi desert. It describes models ranging from conservationist models used for large areas to more recent experiments and socio-technical choices implemented on smaller scale-fenced parcels. Through two central water places located in North Horr and Kalacha, we also describe the impacts of natural protected areas on pastoralist livelihood in the Chalbi desert. This situation, therefore, prompts for suggestions to discuss the split between environmental conservation and development and to better integrate research on socio-ecological dynamics in environmental policies.
\end{abstract}

In many Arid and Semi-Arid Lands (ASALs), environmental policies often correlate with natural resources on which the livelihoods of the inhabitants depend. The creation of protected areas is thought to be one of the most cost-effective ways of conserving biodiversity (Ervin, 2003). Over the last 20 years, Northern Kenya has seen implementation of various models for the protection of natural resources for biodiversity conservation. Northern Kenya comprises various natural protected areas endowed with immense biological diversity and water, which provide vital ecosystem services. The existing social and political organizations also depend upon the dynamics of both these natural resources as well as implications of the existing protected areas.

At the same time, these conservation practices tend to inhibit some of the vital functionality of those areas, for the pastoralists' livelihood in particular. In Marsabit County, many fenced areas have been used as dry season grazing and watering areas for generations in order to sustain pastoral activities. Today, these bio-cultural heritages are prompting questions

\footnotetext{
${ }^{1}$ Institut Interdisciplinaire d'Anthropologie du Contemporain, UMR 8177 CNRS/EHESS, Paris. Email bhazard@ehess.fr

${ }^{2}$ Ecole des Hautes Etudes en Sciences Sociales, Paris.

Email Christine.adongo@ehess.fr, adongoc@gmail.com
} 
about involvement of the inhabitants in enhancing the sustainability of their environment and livelihoods. Why is this the case, and how can conservation goals and pastoralists activities be better integrated for their mutual benefit?

Through analysis of the interactions between protected areas and the dynamics of pastoral economies in Northern Kenya, our research questions the past and present socioecological functions of the greater Marsabit ecosystem. It queries issues around natural resource governance in a continuum of protected areas (including forests, water and pasture), occurring on different scales (local, national, international) in the context of environmental change. After presentation of the study area, we first argue that protected areas can be seen as a socio-technical tool for conservation, which has emerged along the colonial assumption of the inability of pastoralists to manage their resources. Consequently, we underline the tools for conservation, such as protected areas that reflect past and present hegemonic views on nature. We then discuss existing models that reflect the major orientations of conservation since the nineteenth century. Ultimately, through the case of two protected areas-two springs in North Horr and Kalacha, which have been central in pastoral mobility in the Chalbi desert, we underline the impact of global environmental concerns on pastoralist activities today. As such, the interaction between protected areas and the dynamics of pastoralists' economies is part of the debate on environment. It refers to a benchmark of global and national public policies, in a context where the relevance of 'protected natural areas' is related to their ability to become either a 'tool for development' or just the conservation of remarkable natural heritage (Aubertin et al., 2008).

Broadly, our work is based on a mixed methodological approach, utilizing both qualitative and quantitative techniques. Key informant interviews, focus group discussions and participant observation enabled us to gather invaluable information from both the local inhabitants and implementers of protected areas. For instance, we were able to discuss pastoral mobility, livelihood options, protected areas at different scales, boundaries, management structures, access regulations, grazing and water areas, resource use, and conflicts. We also found it useful to map significant sites such as the protected areas at different scales, water and grazing areas.

\section{The study area: an ecosystem facing environmental stress}

The Marsabit greater ecosystem comprises Inselbergs of volcanic origin of up to $1700 \mathrm{M}$ ASL compared to the surrounding semi-desert (400M ASL), and covers the endorheic basin of Chalbi desert (an old lake bed). Categorized as one of the driest regions in Kenya (Marsabit District Development Plan, 2010), this ecosystem faces severe challenges related to natural resource access and availability, particularly water and pasture. Dire consequences of a highly variable climate further exacerbate the resource scarcity problem. Generally, the Marsabit 
Les Cahiers d'Afrique de l'Est

County has a semi-arid climate with poor soils, except for some high altitude areas. Rainfall is erratic (800-1000 $\mathrm{mm}$ in the highlands and $200-250 \mathrm{~mm}$ in the lowlands), unreliable and highly variable both spatially and temporally. There are no permanent rivers in the entire county and vegetation is sparse due to low rainfall and high-rate salinity soils.

\section{Map 1: The endoreic basin of the Chalbi desert (Marsabit County)}

\section{Situation map}

The endoreic basin of the Chalbi desert (Marsabit County)

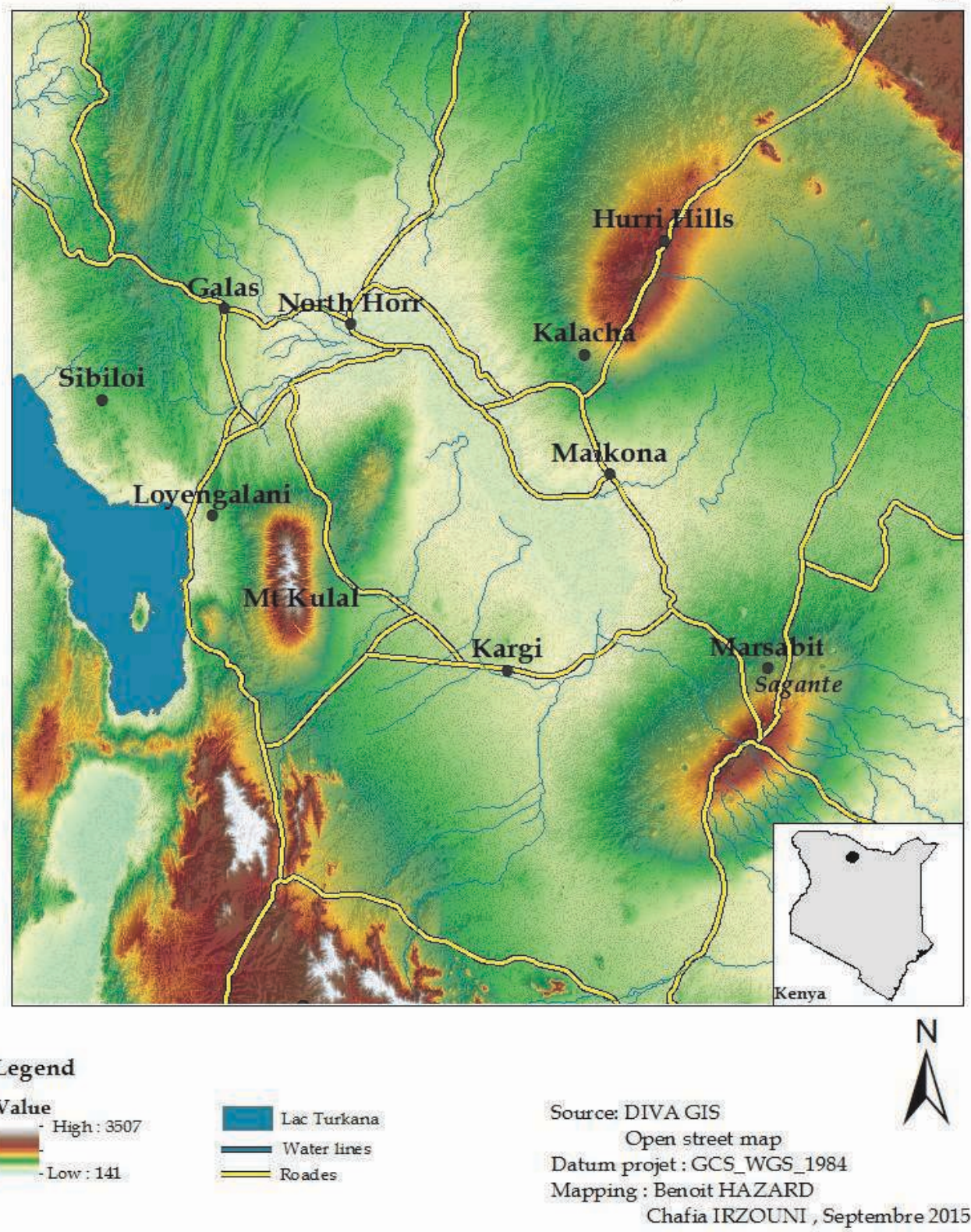

Chafia IRZOUNI, Septembre 2015 
Marsabit is amongst the most sparsely populated counties in Kenya (1.98 inhabitants $/ \mathrm{km}^{2}$ ). These low densities reinforce a widely held assumption that pastoralists from rural areas form the bulk of rural migration to urban centres such as Marsabit town where the urban population has increased 10 times (5000 inhabitants in 1963 to 50,000 in 2011) within the last four decades. Although the highlands have attracted pastoralists since the colonial era, the pastoralists have never been allowed to settle. In fact, these areas were the refuge for victims of war and drought after independence, when mass movement to the mountain area started in 1970s as a result of the Somali secessionist war (1970s), large losses of livestock from droughts (1973/74) and the Ethiopian war (Witsenburg \& Adano, 2007). Broadly, many towns of the county (Maikona, Kalacha, North Horr, Hurri Hills) have developed as a result of a similar process.

Inhabitants of Marsabit County are dependent upon the available natural resources. An interview with the chief National Environment Management Authority (NEMA) officer of Marsabit County revealed that, approximately 1000 tons of dry firewood is extracted from Marsabit forest annually. Environmental conditions enable inhabitants to practice nomadic pastoralism and make use of communally shared natural resources (water, pasture). In a 'water scarce' country (the natural endowment of renewable fresh water of Kenya is $647 \mathrm{~m}^{3}$ per capita/annum), Marsabit County is characterized by inadequate water availability and poor water quality as a result of salinity, pollution, poor water supply services by the county government, and a complex water management system. Pasture is essential for the herds' survival, and thus flexibility in search for pasture especially during drought is a strategic activity to bolster livelihood options. Since 2000, increased incidences of severe drought have increased the vulnerability of natural resources. Pressure on the highlands 'mist forestprotected areas' is accentuated by land grabbing and seasonal concentration of livestock from the lowlands, which utilize the highlands as a dry season grazing area. The encroachment not only signifies the genesis of resource degradation (soil erosion, over-harvesting, biodiversity loss) but also contributes to the escalating resource use and human-wildlife conflicts (Witsenburg \& Adano, 2007). At the same time, the growing numbers of protected areas in an ecosystem where resources are scarce tend to reduce rangelands that are available to pastoralists. This situation can not only culminate in violent resource use conflicts between different ethnic groups (mainly Rendille, Gabra and Borana), but also drives the formulation of new conservation models that are more inclusive, such as conservancies.

Implementation of public policies in Northern Kenya seems plausible because of the socio-economic inclusion of Marsabit in a new geopolitical scenario with the creation of South Sudan state (North East), the South Sudan Ethiopia Transport Corridor (LAPSSET) initiative and their related developments (roads, railway, pipeline, power lines, wind farms, resorts). This positions northern Kenya at a crossroads of a new geopolitical situation. Inadequacy of the state governance has given a de facto power to non-governmental 
organizations (NGOs) on which a growing number of inhabitants depend. Furthermore, a debate is emerging about the place and role of communities in conservation and resource management. All these factors question the governance scales of various natural resources in the pastoral landscape of Northern Kenya.

\section{Natural resource policies in arid areas}

For a long time, the implementation of protected areas in Northern Kenya has been the key to the relation between pastoral societies and environmental dynamics. It reflects that the role of pastoralism in rangeland management and ecosystem dynamics has been and is still widely misunderstood (Anderson \& Grove, 1987; Homewood \& Rodgers, 1991; McCabe, 2004); it is also due to the fact that protected areas were formulated as a heritage of conservationist approaches at the expense of the local societies. As such we argue that protected areas are not a pure idealistic model for conservation but embody hegemonic representations of nature related to social and power relation to control natural resources. As such, protected areas are socio-technical tools reflecting one specific form of appropriation of nature, which cannot be disconnected from a specific understanding of ownership.

Conservation policies cannot be separated from the control of natural resources during the colonial time. They have shaped the understanding of pastoral societies as a backward irrational system that involved inefficient use of the resources (Warren, 1995), building the dogma of their responsibility for the rapid environmental decline. Both researchers and African bureaucrats share this view (Rossi, 1998; Schlee \& Shongolo, 2012) and such assumptions have excluded pastoralists from environmental projects (Rossi, 1998). One source of this exclusion is expressed in the functionalist controversy between partisans of equilibrium and non-equilibrium models that were promoted by followers of range ecologists. The former believed in Clement's 1916 model of succession and ecological stability, which uses carrying capacity and stocking rate parameters (Warren, 1995). However, these models do not consider the complex relationship between rangeland and livestock, the varied climatic conditions within the range, and different animals' feeding habits (Toutain, 2008). The nonequilibrium model holds that, climate drives the system and that pastoralists adapt by controlling the herds so that at any time the balance necessary for the preservation of the environment is not disrupted. However, critics argue that in arid zones, oases are often present, and therefore primary production in such areas is not entirely rainfall dependent. These areas may have enough forage to prevent the die-off of livestock during drought, thus reducing the effect of climate variability on livestock (Joly, 2008). In addition, this model does not consider that livestock surviving on wetlands could have detrimental effects on neighbouring arid rangelands. Broadly, the lack of a rationality of pastoral systems led to the exclusion of indigenous conservation mechanisms in natural resource policies (Rossi, 1998). 
This antagonistic view of pastoral use of natural resources and conservation policies explains why protected areas have been adopted as a socio-technical tool for conservation instead of local conservation practices.

Another motive for this antagonism is linked with the lack of recognition of pastoralists' land rights. After independence, the implementation of many protected areas was possible because pastoral land uses were not recognized as a form of ownership or collective rights. In Kenya, pastoral lands have been perceived as a waste of space, and successive administrations have considered them 'free' lands (Rossi, 1998). The land uses of territories then, were based on the hegemony of a Western conception of livestock production. The allegedly environmentally harmful practices and economically inefficient pastoralism was used as a scientific and political argument to exclude pastoralists from the regional market (Schlee, 2012). The relationship between overgrazing and soil erosion was the main motive used by colonial administration to introduce "tribal grazing areas" and a "belt quarantine" to disrupt pastoral mobility (Homewood and Rodgers, 1987; Anderson, 2002). Again, regulation of nomadism was used to structure a dual livestock economy (ibid). This desire to prevent further environmental degradation by pastoralists, encouraged sedentarization policies in the 1980s. By settling people and livestock on small parcels and increasing carrying capacity on permanent and restricted pieces of land, land degradation has been encouraged leading to widespread desertification (Hogg, 1987; Fratkin and Roth, 2006). In this process, the establishment of protected areas and the appropriation of land for environmental reasons are the two components for the destitution of pastoralists, that Fratkin and Roth (2006) attribute to a cycle bonding together with recurring droughts and diminishing rangelands, expands arable agriculture into former pastoral areas. To some extent, political and scientific discourses have legitimized the conversion of pastoral lands to ranch lands belonging first to colonial farmers and later to the new Kenyan elites. In ASAL areas, the inability to develop viable agriculture resulted in an increasing number of game reserves and protected areas around attractive natural sites.

\section{Management of natural resources and socio-technic of conservation}

Marsabit County has at least a dozen protected natural areas, different models for natural resource management, and legal statuses. These protected areas reflect three major orientations on the conservation timeline since the nineteenth century: the colonial model 'sanctuary of nature', the inclusion of social dynamics, and the 'return to the barriers' in a global environmental discourse. These orientations are used as a benchmark to describe the various protected area models in a simple typology. 


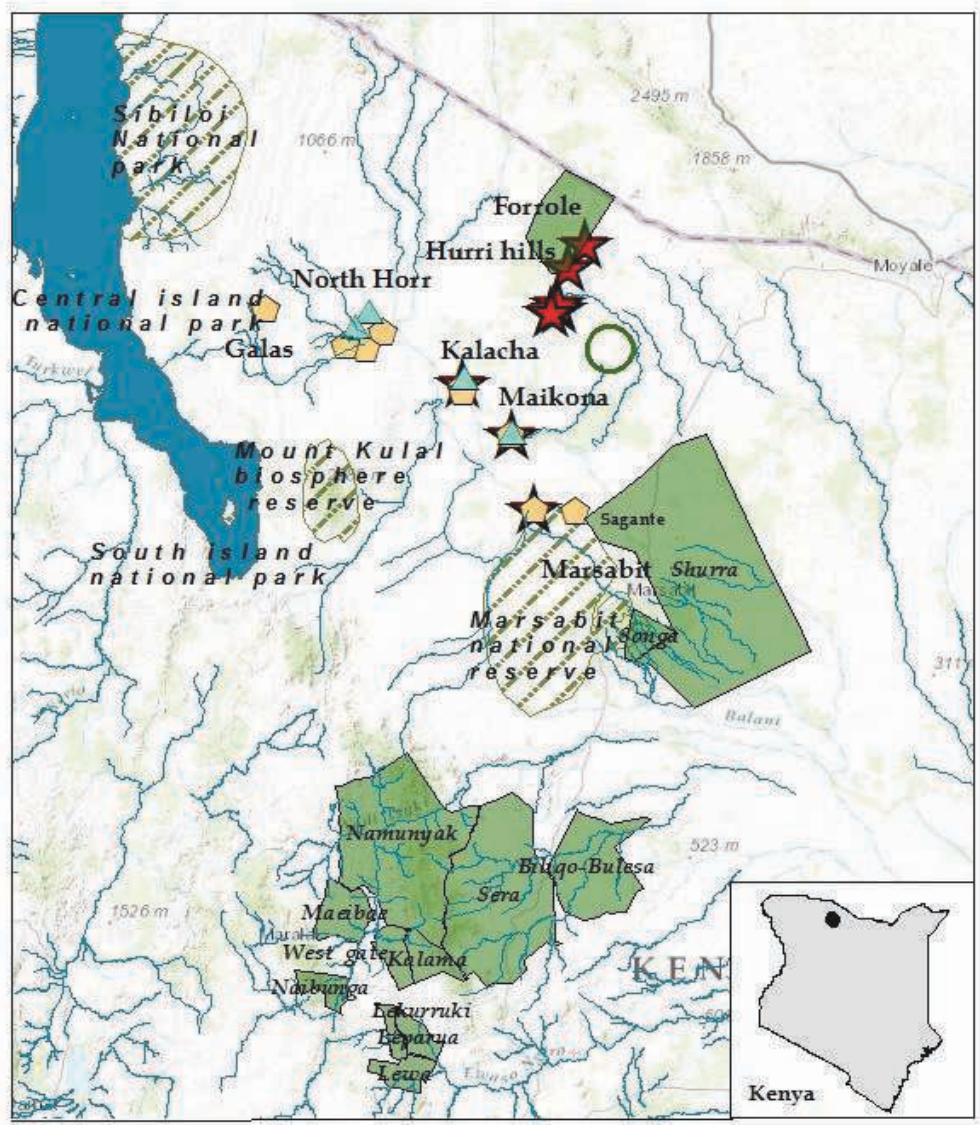

\section{Légende}

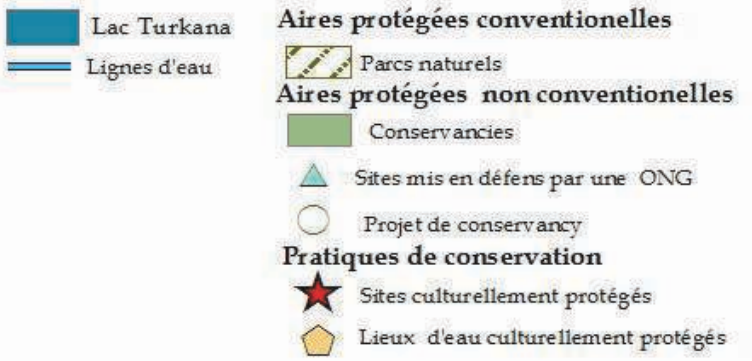

\section{Source: DIVA GIS}

Open street map

Datum projet : GCS_WGS_1984

Mapping : Benoit HAZARD

Chafia IRZOUNI, Septembre 2015

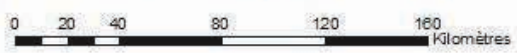

The first group is represented by national parks and reserves such as Marsabit and Siliboi. These are sites that date back to colonial times. The second group comprises large biosphere reserves (Mount Kulal) created in the 1980s. Parastatal institutions, whose regulations conform to international conventions, manage these two groups. The third group 
is represented by recent models promoted by new stakeholders such as NGOs, which attempt to involve local communities in the management of natural resources. Due to their multifunctionality, protected areas lack a unifying theoretical structure (Ervin, 2003; CormierSalem and Bassett, 2007). They can thus be characterized as an experimental framework at the intersection of conservation/protection of biodiversity and development (DeFries and Hansen, 2007; Defries et al., 2007), between users and resources of conservation, science and public policies (Granjou and Mauz, 2011). In other words, the model of a protected area depends on the priority given to social or ecological aspects, the management scheme adopted and the existing technological possibilities. They reflect at least the inclusion/exclusion of social or technological solutions to manage the natural resources.

\section{Marsabit National Park and Reserve (MNPR)}

The Northern Kenya wildlife conservation project undertaken by the Ministry of Forestry and Wildlife, has formed the core of the conservation and management of MNPR on policies linked to a situation of "ecological apartheid". MNPR is a heritage of the "game reserves" and showcases how promoting the protection of nature was undertaken by the conservationists" movements in the early twentieth century to impose their ideas of conservation and experiments in colonial parks (Anderson and Grove, 1987; Selmi, 2009). The total land area of $6450 \mathrm{~km}^{2}$ was approved in 1900 and became the Northern Game Reserve in 1902.

MNPR illustrates how the view of pastoralists' rangeland as free land allowed colonial resource alienation in the name of conservation of an Eden (Grove, 1995). It can be seen as a historical example of "green grabbing", i.e "the appropriation of land and resources for environmental ends" (Fairhead et al., 2013: 238-239) which over time has led to novel valuations and commodifications of aspects of nature ( ibid). Indeed the green agenda linked to the creation of Marsabit National Park is related to the debate on the creation of game reserves that occurred during the 1920s between the local white farmers and the British elites

In this context, Marsabit forest MNPR was publicized in the 1920s through the myth of a lost lake in Northern Kenya narrated by Martin and Osa Johnson, who were two American adventurers. Martin and Johnson discovered a Crater Lake hidden in Mount Marsabit forest, and later renamed it Lake Paradise. They were supported by Arthur Blayney Percival, a professional film director and a naturalist, who was appointed as a game ranger by the High Commissioner Sir Charles Elliot (Imperato, 1999). The image of the lost lake in a pristine forest later contributed to the representation of this natural area as an Eden (ibid), a "climax", or an image of the virgin nature exclusive of all human actions and related to the wilderness model (Larrère, 1993). More broadly, the Johnson Safari in Marsabit shows how hunters, foresters and the British elite promoted the protection of nature and contributed to the ultimate 
national conservation policy (Berdoulay \& Soubeyrans, 2000). As a first result, the actual boundary of Marsabit National Park was designed according to the gazetted Crown Forest reserve (1932), which covered the forest area. According to the model of nature as a sanctuary, distinction between the park and the reserve, which comprised the protected area, was later designed around a hard core. A central zone isolated from human activities when Marsabit National Reserve was gazetted and placed under the management of the Royal National Park of Kenya (1948). As a result, Marsabit protected area comprises a National Park and a National Reserve, which have an unclear legal status. In 1985, the first legislation (Forest Act Cap 385) defined the status of Marsabit National reserve in order to mandate the Wildlife Conservation and Management Department (Kenyan Wildlife Service) to manage the reserve.

This legislation was completed in 1990 by a demarcation survey to realign the boundary between Marsabit town and the National Reserve. The main goal was not to clarify the status of the protected areas but to adjust the boundary of the protected area with respect to the sprawling town. Settlement schemes on Marsabit Mountain were established between 1970 and 1980 as consequences of the above-mentioned conflict and climatic conditions. Witsenburg and Roba (2004) report that these settlement schemes were implemented following the colonial model of "tribal areas". Since the National Council of Churches in Kenya (NCCK) in collaboration with the missionary, Anderson started a settlement scheme in the mountain for impoverished Rendille pastoralists from Laisamis in Songa, Nasikakwe (Karrare) and Kituruni in 1973. The government and the Catholic Mission designed Manyatta Jillo and Sagante for the mainly impoverished pastoralists who lived in urban slums of Marsabit township (ibid).

Just like the implementation of new settlement schemes, the unclear legislation on protected areas underline the policy gap on land allocation, rights and uses, such as the need to integrate settlement schemes in the protected areas' management plan. First, the situation has increased land and resource use, resulting for example in the encroachment into the forest created by the previous settlement scheme, which is used for agro-pastoralist activities by the Rendille and claimed by the Boranas in Badasa as a dry season grazing area. By confining societies to "tribal grazing areas", the authorities have emphasized ethnic identities, increasing the need for self-reliance. Second, it has prompted the Kenya Wildlife Service (KWS) to manage the area as a de facto National Park and to some extent allow access to natural resources by opposing pastoralists' activities to conservation as explained by a warden of the park:

"During the dry season, we have a lot of problems because most pastoralists rely on water located inside the protected natural area. But these pastoralists cannot have access to water without destroying vegetation and cutting the trees that block access to the water. During the dry season, we allow them to go into the forest, we 
allow them to come up with livestock and to water, and then we're out of the woods ... But sometimes some come for watering livestock and they remain there, cut vegetation and have illegal activities inside the protected area."

This opposition in natural resource management has compelled the park manager to develop a new strategy for land use. In 2002, KWS attempted to purchase land in order to secure its management through an extension of control over space and the implementation of new wildlife corridors. This green grabbing project sparked a violent conflict between the managers and inhabitants of Marsabit, who argued that such projects do not benefit the inhabitants who in the past had traditionally managed the resources communally and were dispossessed of their pastures. A realignment of the boundaries was undertaken in 2003 to include some of the forests and dry season grazing areas omitted by the previous National Park (AFD, 2011). In accordance with the regional context, a new management plan, as part of the Northern Kenya Wildlife conservation project, has emerged proposing to ensure effective management through a network of protected areas and community conservancies. Based on the adaptability of communities to change and on the ability of protected areas to provide ecosystem services over the long term; the split between environmental conservation and development was highlighted as the current goal for natural resource governance. This framework has enabled the development of activities to reduce environmental degradation, to solve the problem of water scarcity, to enhance water supply and irrigation scheme of the lowland, and to fund a dam with a private operator. Several conservancies have generated an economic model to facilitate community development through initiatives of environmental conservation (AFD-Northern Rangeland Trust project). Meanwhile, this switch to community management as part of the flexible legal framework of common locus has facilitated the practice of 'land grabbing'. The unclear legal framework defining lands rights, parks and community areas may limit the ability of the authorities to implement conservancies and community-based projects. Originally proposed to respond to the challenges related to the type of compensation received by the people for their lost land, conservancies have in fact copied the colonial tribal grazing areas. They raise the question of how to define community areas and appropriate political structures in a context where the conflicts between communities who depend on these resources remain the main management challenge of natural resources. This redefinition of conservation projects is also accompanied by a back to the gate, i.e. a return to the isolationist principles (Aubertin et al., 2008). The fact that inhabitants cross the electric fences around the perimeter of the forest to have access to resources, is symptomatic of current difficulties in managing colonial legacies, through the previous model. 


\section{Sibiloi National Park}

Lake Turkana National Park (161,485 ha), located on the Northeastern side of the lake, is a conservationist project to ensure the long-term protection of fossil sites and conserve endemic biodiversity. The creation of Sibiloi National Park by the Kenyan government in 1973 was due to archaeological and paleo-anthropological research in the 1960s. From the discussion with an archaeologist who has worked in northern Kenya since the early 1970s, the discovery of a variety of fossils including hominid fossils in Koobi Fora had great influence in the design of the park as the cradle of Mankind, a museum and a research base. Similar to the tradition of game reserves, Sibiloi National Park was first designed for researchers, naturalists and tourism as a place mixing fossils and wildlife. Although pastoralists (Gabbra and Dassanetch) are allowed to bring their livestock during dry seasons, they cannot reside in the park in accordance with an agreement with the local authorities. In particular, these are access rights for the local pastoralists to graze and to water livestock in case of difficulties, and access rights for the County Council to undertake « any sort of activity which may benefit the Council. Inaccessibility of the area and lack of arable land have permitted the survival of species and have contributed to the myth of an isolated area. In this context, the picture of "the origin of mankind" has played a key role in the design of the regional environmental conservation and to some extent to experiment a model of National Park on a regional scale.

The park was enlarged and renamed Lake Turkana with the inclusion of two important offshore zones (Central Island National Park in 1983; South Island National Park, in 2001), which offers, "a panoramic view of scenic landscapes set in expansive areas of wilderness" (http://www.sibiloi.com/). The two sites are extinct volcanoes rising out of the middle of Lake Turkana and are important breeding grounds for crocodiles, hippopotamuses and a range of venomous snakes (Debonnet and Gugic, 2012). Moreover, South Island is defined as one of Kenya's Important Bird Areas (IBA) and a key stopover point for Palaearctic migrant water birds (ibid). This combination between geological landscape, wildlife and archaeological sites was used as the main argument to list the site as a UNESCO World Heritage Site in 1997.

Despite conservation attempts, the park faces ecological decline, particularly with respect to the availability of water for plants and wildlife because of the major changes that have occurred over the last thirty years. A recent assessment (UNESCO, 2012) states that data on wildlife is not available and that some species (such as giraffes, gravy zebras) have been exterminated from the park. On the Island, the population of crocodiles has declined due to the involvement of pastoralist communities in fishing activities to adapt to drought and famine. First, the long-term stability of this fragile dry-land ecosystem appears to be overstressed by drought, demographic pressure and pastoralists' uses. One of the reasons for this stress is the massive change in many grazing areas, especially from the North of the Ileret River to the North of the park. Although the lake levels of Turkana have fluctuated over the 
last 10,000 years, change in grazing areas and the anthropogenic pressure on the park have increased:

\section{"While at the time of creation of Sibiloi National Park, grazing and watering rights were given to the local people in case of difficulties and while a certain corridor was agreed, today grazing seems widespread across almost the entire national park and throughout the year" (Debonnet \& Gugic 2012: 33).}

According to the aforementioned archaeologist, the structure of the biological communities is determined by a lack of water and the species present reflect the adaptation to both moisture availability and the high alkaline levels close to the lake. Today, stability of this dry-land ecosystem depends on the hydrological dynamics of the Ethiopian Highlands and drainage into the Lake Turkana through the Omo River. Sean (2014) suggests that change in human subsistence strategy, such as conversion of grazing land into farmland using more water along the Omo Rivers, impacts the lake levels, grazing areas and vegetation. In that sense, this isolationist model would be irrelevant to take into account the complex interconnectedness of vegetation, wildlife and domestic stock. It ignores the connectivity between protected areas and the regional environmental change.

Second, natural resource dynamics questions the efficiency of this model. On the one hand, the construction of the Gibbe III dam on the Omo river upstream of Lake Turkana threatens not only the fragility of this ecosystem, but also valuable rangelands in the Omo delta. This increases the competition over grazing areas in Sibiloi National park. Debonnet and Gugic (2012) note that the Omo delta plays a key role for the park by providing grazing opportunities during the dry season and reducing pressure on the park. On the other hand, the recent oil exploration blocks covering Sibiloi and South Island National parks contradict the initial goal of the conservation project. It also poses a management conflict between the KWS, a government parastatal established by the Wildlife Conservation and Management Amendment Act of 1989, and the National Museums of Kenya (NMK) in charge of the management of the fossil sites (ibid). Although KWS officially manages the park, until recently there was no permanent presence of the warden in Sibiloi and South Lake National Park.

The Marsabit and Sibiloi model reflects how conservation schemes elaborated in Europe in the early nineteenth century have been implemented through local experimentation in Africa. These two examples show the difficulty of these conservation models to adapt to change and take into account the conservation practices of pastoralists in their management plans. 


\section{Mount Kulal biosphere reserve}

Mount Kulal $(2,416 \mathrm{~m})$ is situated on the Eastern side of Lake Turkana. It is an eroded volcanic peak with a deep crater, capped by rain and covered by a mist forest. It is organized in a core zone of $11 \mathrm{~km}^{2}$ and a buffer of $7000 \mathrm{~km}^{2}$. In the $1970 \mathrm{~s}$, the primary conservation model allowed the connection of "environmental concerns" to the "development ideology", which influenced the global guidelines of conservation movements. Mount Kulal became a place for experimentation of a second model of protected area with its designation as a Man and Biosphere Reserve by UNESCO in 1979. Mount Kulal reserve comprises a volcanic landscape with an extensive lava desert, the Kajarta gorge, hot springs, the occasionally flooded Chalbi desert, sand dunes and seasonal watercourses. These natural features indicate that landscape has played an important role in the choice of sites, and how this protected area was created in the wake of the making a spectacle of nature (Selmi, 2009).

Unlike the previous model, Mount Kulal conservation project mobilized an ecosystem approach. The project to save the remarkable forest was designed from the understanding of biotic systems supported by the mountain in the midst of an arid land. As described by Watkins and Imbumi (2007:33): "The Mountain ecosystem captures moisture in the forms of mist and rain and provides important hydrological services for the entire region". By underlying the function of the forest in a broader ecosystem (forest-desert) this MAB project shifted the locus of conservation from a single locus (the forest) to the understanding of regional environmental dynamics, such as the central role of mist forests (Kulal, Marsabit and Hurri Hills) in the hydrological cycle of the Chalbi. More importantly, this approach highlighted the interactions between protected areas, livelihood and the maintenance of ecosystem services in the forest conservation project. This partly explains why the site was designated UNEP-MAB Integrated Project on Arid Lands (IPAL) amidst intense socioeconomic and natural science research from 1976 to 1980.

Although the Kulal forest is a MAB reserve, its legal status remains unclear. Until recently, the Kenya Forestry Research Institute was in charge of the programme management, but the forest has no legal status. As noted by (Watkins \& Imbumi, 2007: 34): "Landownership has not yet been put to the test legally at Mount Kulal nor elsewhere in northern Kenya. But the uncertain land tenure situation represents a challenge for conservation management planning."

Unlike the isolationist models, this unclear legal status did not culminate in the total exclusion of human activities. The MAB reserve falls in Loiyangalani division, and comprises six villages with approximately 1200 Samburu and 1200 Rendille households. The main village, Gatab (1700 m) was created by A.I.C Missionaries in 1967 to bring medical and educational services closer to Samburu pastoralists, who use the place as a dry season grazing area. Paradoxically, the environment generated by conservation actions raised new questions. 
On the one hand, the infrastructures (woodland fenced previously for research and livestock station, shallow well) implemented during the UNESCO / IPAL project have created new activities but are also pockets of poverty. For example, the sub-location of Olturot, which is favourable to pastoralists because of their richness in salt licks, pasture and water, illustrates a new pressure on the forest: "Due to its strategic position and enough pasture, water and easy access the town became a business centre especially for livestock marketing and Merchandise guards for Arapal and Gatab centres" (Marsabit district report, 2007). As in other areas, this new situation is also reflected by diversification of traditional Samburu pastoralist livelihoods by increasing reliance on agriculture for subsistence.

Socio-environmental assessments have not been conducted since the establishment of the biosphere reserve. Kulal represents a tipping point for "emergence of a new model of protected areas to integrate experiences of participatory management in conservation" (Aubertin et al., 2008). Changes resulting from the project have prompted the Community Development Committee (CDC) to implement environmental education to enable the inhabitants to analyze development activities and their environmental consequences. Moreover, the lack of legal status has led local communities to manage through various group and committees (youth club environmental committee, water committee). For instance, the previous IPAL guard project to limit grazing inside the forest was replaced by a community surveillance team and elders who allow livestock to graze in the forest in case of severe drought (ibid). The water committee, a part of the local village council, is responsible for the management of the water system and any possible extension of it in the villages. Beyond management, the involvement of communities mobilize traditional pastoral knowledge and practices on conservation, such as plants and trees that are protected, and are associated with Samburu rituals (Ficus thonningii, Ochre). These socio-fences seem to be a more effective means of protection compared to physical fences. They enhance conservation and participation of the local community and encourage environmental education.

Beyond the conventional definition of protected areas, the question of conservation knowledge and practices has been central in the implementation of Kulal MAB, showing the need to improve conservation knowledge over different times scale to assess the role of protected areas in human/nature evolution and adaptation. As a result, a new trend of research and conservation has led to the involvement of local communities and their conservation practices in the management of the park. More broadly, the implementation of Kulal MAB reserve raises the concern of integrating protected areas in local territories and the management of resources by local actors. 


\section{Protected areas of North Horr and Kalacha (Chalbi desert): Between barriers and transition of pastoralists economies}

In Northern Kenya, the emergence of a new model of conservation is partly due to the increasing involvement of NGOs in addressing increasing vulnerability of natural resources. For NGOs working to prevent drought and food crisis, protected areas represent an important component in risk management of natural resources. In Marsabit County, various trustees who are either specialized in conservation such as the Northern Rangeland Trust (NRT) or, are involved in environmental project such as many NGOs promote these approaches. Theses heterogeneous organizations implement various conservation projects going from conservancy model to areas that are fenced for vegetation rejuvenation. They reformulate the debate on protected areas between return to barriers and community management. On one side, conservancies, a model combining conservation and livelihood, was based initially on an idealistic philosophy, which refers to the community as the only group able to establish and maintain a harmonious relationship with nature. In that sense they promote a communitybased management model of natural resources. But on the other side, the areas for conservation demarcated from the rangelands with incentives from the NGOs, shows that the exclusion of pastoralists' practices in conservation persists.

Since the mid-nineties, these approaches have been developed in relation to successive severe droughts $(1997,2009)$ and their impacts on natural resource rejuvenation. They are part of changes that occurred in the global environmental system although they remain an unwell identified object in environmental concerns (Chartier \& Ollitrault 2005). In light of this context, Kalacha Dida, a historical spring in the Chalbi desert and Horr Goda, a fresh water spring in North Horr, have been rehabilitated and fenced by these humanitarian NGOs in collaboration with the local communities and government representatives. These watered places both have ecological and socio-cultural significance and as natural sites have been strategic in the genesis of the towns of Kalacha and North Horr.

\section{Horr Gudha spring, North Horr}

North Horr is one of the few towns within the county that is a historically watered place and that has benefited from a tap water system. It was created in close proximity to three springs. The first, Horr Gudha, is the most commonly used spring both for domestic and livestock meanwhile, Horr Dika and Renderi Gudo, are preserved for livestock. Despite the existing tap water system, the inhabitants still preferred Horr Gudha spring, which is a historical water source for local inhabitants not only because of its freshness but also because of the socio-cultural significance it holds (Hazard et al., 2012).

Horr Gudha spring has been used for generations as the major watering point for livestock, wildlife and for human consumption. It is thus one of the most important sources 
marking the livestock routes to watering grounds within this area. Besides the socio-cultural importance, this source provides a green space that breaks the monotony of dry shrubs and sandy landscape marring most of the region. An observation of several watering points within North Horr town indicates that some inhabitants use these water sources for socialization (ibid). This spring supports several fauna and flora species, which use it either as habitat, feeding, breeding and/or watering ground. It marks an important migratory route for the avifauna. Not only is Horr Gudha a water point like many others springs in the area, it was also a water place.

As is remembered by the inhabitants, Horr Gudha is protected today, and accessibility is regulated unlike in the past, when its management was entirely vested on the community, for example through the Council of Elders. During this past period, water access was regulated for livestock but not for domestic uses. But since the spring was fenced for conservation and sustainability by some humanitarian NGOs, water use has been regulated. In-depth interviews with informants reveal that Horr Gudha's protection was initiated partly due to overutilization and apathy of local inhabitants toward its conservation.

"Before its conservation, livestock and people used this water anytime and no one cared to clean up after their livestock, for this reason, the spring became filthy as livestock dung and other filth piled up, blocking the spring, the water started drying up," explained one elder from Malabot.

Initiatives of humanitarian organizations promoting resilience in pastoral communities through disaster risk reduction (DRR), involves the clean up and fencing of the spring. Thereafter, water channels were constructed to deliver water to livestock outside the spring. The idea was to limit access to water from the point source and create a buffer zone to enhance vegetation regeneration. The motivation for conserving Horr Gudha seems to have been implemented as a DRR/humanitarian strategy rather than ecological/natural resource conservation strategy or for socio-cultural consideration. Indeed, one of the DRR strategies is to enhance resilience and adaptive capacity to environmental disasters (De Jode and Tilstone, 2011). With a sustainable water source like Horr Gudha, access to water supports livelihoods and could enhance food security.

Although Horr Gudha conservation has ensured water resource availability and sustainability; its implementation overlooks the socio-cultural significance of the spring and its social representations to the local inhabitants. Moreover, water is now available at a cost? Inhabitants pay a monthly fee to access erratic tap water and can only fetch water from the spring at stipulated hours, lamented one woman who had just crossed the fence of Horr Gudha: "The gate is usually locked it means to access water we have to jump over the fence, and this is risky because it is against the regulations, but we prefer this water so we do it" 
Whereas this historical watered place was felt (was embodied within the pastoralist socio-political system and regulate by the Algana clan $^{3}$ ) to belong to the pastoralist system, today it is regulated by the NGOs that rehabilitated it, since they control water access through a padlock at the gate and a guard employed to keep out trespassers (Hazard et al., 2012). With limited access to the spring, many pastoralists' activities such as trade in livestock and other forms of sociability are no longer important. Fences have changed not only the sense of ownership of the spring but also the social nature of the place, since in the past water was embedded in local, social and political relations and territory. In that sense, this protected area exemplifies how water as a substance entirely devoid of social content appears for pastoralists. It also reflects how the implementation of new models for the management of natural resources contribute to what J. Linton (2010) described as "the invention of water as a modern abstraction". The conservation project of Horr Gudha thus changes the value of water as a resource to water as an economic good, which is uni-dimensional, quantitative, monetarized, scarce and which therefore allows for the creation of a local water market.

New stakeholders have been introduced in natural resource management that challenges the pastoralist system in a context where natural resources are scarce. But these watered places were strategic for pastoralists in their seasonal movement patterns for generations, which emanated from adaptation to an endoreic basin organized around an aquifer system linking the highland to the lowland. Horr Gudha, for example, is a significant dry season watering ground. It thus exemplifies the need to seek a balance between environmental policies, governance of resources and their social constructions. Sustainable resource management begins with an enhanced sense of ownership by local inhabitants, without which conservation efforts are often doomed due to community apathy. Again, the fencing of this spring has to some extent provided the population with an alternative, the piped water system. Despite the challenges this system is facing, it can be looked at as an attempt to balance conservation and development.

\section{Kalacha Goda and Kalacha Dida Springs in Kalacha}

Within the Chalbi lowlands, Kalacha is the only place where water is plentiful. Endowed with numerous wells and two historical springs, Kalacha Goda and Kalacha Dida are located at the nexus between the highlands and the lowlands. Kalacha town has successfully diversified pure pastoralism with agro-pastoralism with help from NGOs (Solidarités and Pastoralists Initiative Support Program) and state agencies such as Kenya Agricultural Research Institute (KARI).

Both springs have been important watered places that defined livestock routes in the dry season, and water availability has played a significant role in the genesis, growth and

\footnotetext{
${ }^{3}$ Algana is one of the four clan of the Gabbra who are inhabited the Chalbi desert.
} 
development of this town. Its inhabitants say that the waters of Kalacha Dida have flowed freely like a fountain ever since they can remember. This meant that the other surrounding areas, as far as Hurri hills highlands depend on this watered place both for domestic and livestock use. During the severe drought of 2011, it was observed that Hurri hills survived on water tinkering services from Kalacha Goda and that it was the source of water, which NGOs and government utilized to supply water deficient areas (Hazard et al, 2012). The importance of this bio-cultural heritage is also emphasized by Kalacha elders who remember the sociocultural value of these areas, which are now fenced for ecological purpose:

"Kalacha Dida and Kalacha Goda existed before inhabitants of Kalacha. The oldest well, Elema Karchowa, was established by the so-called man, when he settled here as a trader around 1975. Before digging his own well, he used water from Kalacha Goda. The name Kalacha Goda means water of kalacha in the palm bush. 'Dida' means plain and therefore Kalacha Dida means the water of kalacha in Chalbi plain. Both Gabra and Rendille used the water of Goda and Dida in the past. There were plenty of wild animals: Gravy Zebra, Elephant, Antelope, Ostrich and Gazelle.

The water of Kalacha Dida is so good for camels and therefore it is praised during the birth of new moon through a song called 'Ebb'. Contained in this song, is a verse: 'Idhiriti guba, yarsimo gall olle, oll balela gall kalacha rabo.' Meaning camels drinking the water from Kalacha Dida run playfully as a sign of happiness and enjoyment. It is good water for camels".

Kalacha Dida is described through the socio-cultural values of pastoralists even if these today include the place in a sedentarized vision. To the elders, the importance of Kalacha Dida does not refer to the function of the spring within the wider ecosystem as they said: “there's no link between Kalacha Dida and Chalbi desert because they found them existing separately". But in their views, the spring is associated with the importance of livestock and water is seen as a bio-cultural heritage. If we consider that this resource was managed by its users in the past, Kalacha Dida is described as a common good. According to the elders, these watered places do not have any owners:

"Kalacha Dida is mainly used by camels only whereas Kalacha Goda was used by people, Cattle, goats and sheep. Rendile and Gabra were its main users in the past. They used these water sources harmoniously without conflict. Therefore it has no history of conflict."

Through this account, the Kalacha springs also have the reputation of having fostered peace in the past, uniting two warring ethnic groups of Rendille and Gabra in sharing the same resource, which happens seldom today. 
From the account above in which the elders say: "The management of these waters is just by the owners of the animals who remove mud in the water channels", it can be inferred that the responsibility for managing, conserving and ensuring sustainability of this spring lay with the local users. It is therefore anticipated that these users would conserve this source knowing the immense value it represented to both the Rendille and Gabra communities, although this was not the case. Inhabitants account that users failed to clean up after their animals causing accumulation of solid waste and consequently a diminishing yet vital resource. The positive impacts of conservation initiatives are that the spring and biodiversity have been restored. For instance, the spring was a habitat for many bird species before its degradation. Kalacha Dida now supports a variety of fauna and flora. This source thus forms an important yet fragile ecological unit.

Kalacha Goda signifies an attempt to create a balance between conservation and development. The management and the utilization of this source has enabled equitable apportionment of water and has derived economic benefits from it. This is seen by the establishment of an agro-pastoral initiative to diversify pastoral livelihoods, as a fallback strategy in time of drought. Initially dedicated to food security preservation through crop production (cabbages, potatoes, water melon), the irrigated farmlands have been implemented in an oasis used for pastoral activities and tourism. With the emergence of new users, water is now shared between irrigation and for watering camels. As such, the farmlands have contributed to define new water regulatory and conservation practices. Crops produced are hay, fodder trees (Lucaena lucocephala), multipurpose trees (Moringa oleifera) and alien invasive species (Prosopis juliflora), used as fodder, building poles for the traditional Mandase huts and for medicinal purposes (Moringa seeds and roots). This irrigation scheme has diversified the livelihoods and reduced the over-dependence on rangelands for grazing. Fodder from the farms is sold to pastoralists who save over $40-70 \mathrm{~km}$ walks to pasture. Hay is an important source of income for the farmers; between $20-25 \mathrm{~kg}$ wet weight is sold at an average of KES 400. In a day, a farmer obtains at least 300-400 KES from fodder or pole sales in addition to livestock benefits.

The Kalacha farms illustrate the conversion of a place first dedicated to food crop production into agricultural practices that are in accordance with pastoralists' values. In that sense, the farmlands of Kalacha represent a protected area where pastoralist conservation practices have been enhanced through socio-fences.

\section{Conclusion}

An overview of the protected areas of Marsabit County shows that there is no predominant form of conservation but a continuum of protected areas created in a specific context that ultimately create an ecological network (Bonnin, 2008). Each protected area 
represents socio-technical choices, guidelines for conservation and political choices that respond equally to pragmatic findings and evolving representations by conservation actors. They are also options at the crossroad of public policies and experimentations. Although the history of protected areas in Marsabit County has allowed the creation of an ecological network, the relations and connectivity between scattered protected areas in order to maintain the wider ecosystem remains a question. The various roles and functions of protected areas, their heterogeneous legal status as well as their management, increase the complexity of understanding of their relation to environmental dynamics at the regional scale. In the same way, the timescale of conservation projects raises the question of their contribution to a sustainable management of natural resources. While the previous conservation models have been implemented as model for conservation and colonial legacy that local inhabitants have to contend with, the current models are implemented for the short term, often fitting with the duration of a project's funding. In most cases, these areas have been implemented for ecological purposes, introducing new stakeholders in natural resource management, and challenging pastoral systems, in a context of natural resource scarcity. Most of these protected areas were strategic grazing areas and were particularly important in seasonal movement patterns. Natural resource management, conservation and protected areas in Kenya have evolved over the last ten years, with gradual inclusion of pastoralists views of Community law regarding natural resources as a form of environmental justice. In Kenya, this has led to the recognition of community land and the right for communities to claim natural resources as in the new constitution. More widely, the western conservationist model of natural heritage focusing on biodiversity is contested by the rehabilitation of communities' rights and community justice system in natural resources management.

Compared to pastoralists' conservation practices, these areas question the role of pastoralist ecology in the management of their rangelands and their contribution to the rangeland health. Similar to the the two important springs of North Horr and Kalacha illustrated, the organizations involved in conservation are not typical environmental conservation NGOs but rather humanitarian groups attempting to enhance livelihoods and bolster adaptability of pastoralist societies to disasters through the implementation of DRR programs. Conservation is thus seen to be complementary to DRR, and essential in enhancing coping capacities. The communities within which natural resources occur are most often mandated with their protection, however, these two cases show conservation initiatives stem from NGOs rather than the local users, who would normally ensure their sustainability. As a result, it is seen that water gained an economic value as opposed to the past when it was a common good. Perhaps this is due to infrastructure maintenance prompting a price tag on water.

The strained relationship between resource users, wildlife and biodiversity conservation today, and the increasing conflict between natural protected areas and the inhabitants, raises 
the question of how conservation goals and pastoralists' ways of life can better be integrated and effectively mainstreamed in management practices and public policies for their mutual benefit.

\section{Bibliography}

Adano, Roba. "Costs and Benefits of Protected Areas: Marsabit Forest Reserve, Northern Kenya". In Economics of Biodiversity Conservation in Sub-Saharan Africa: Mending the Ark, ed. Charles Perrings, 115-138. Cheltenham: Edward Elgar, 2000.

Aubertin, Catherine \& Rodary Estienne. "Le Développement Durable, Nouvel âge de la Conservation". In Aires Protégées: Espaces Durables? ed. Catherine. Aubertin \& Estienne, Rodary, 17-28. Marseille: IRD editions, 2008.

Berdoulay, Vincent \& Olivier Soubeyran. Milieu, Colonisation et Développement Durable: Perspectives Géographiques sur l'Aménagement. Paris: L'Harmattan, 2000.

Bonnin, Marie. “Les Aires Protégées dans la Mise en Place des Réseaux écologiques: Gestion Globale de la Nature ou Gestion des Institutions de Conservation"? In Aires Protégées. Espaces Durables?, ed. Catherine Aubertin \& Estienne Rodary, 113-134. Marseille: IRD editions, 2008

Chartier, Denis \& Sylvie Ollitrault. "Les ONG d'Environnement dans un Système International en Mutation: des Objets non Identifies". In Représenter la Nature? ONG et Biodiversité, ed. Catherine Aubertin, 21-58. Marseille: IRD edition, 2005.

Cormier-Salem, Marie-Christine \& Thomas Bassett. Nature as Local Heritage in Africa: Longstanding Concerns, New Challenges. 2007. pp 1-17. doi:10.3366/afr.2007.77.1.1.

Debonnet, Guy \& Goran Gugic. Mission report. Reactive Monitoring Mission to Lake Turkana National Parks (Kenya), 14-22 2012. http://whc.unesco.org/fr/documents/117237. Accessed 25 May 2013

Defries, Ruth et al,. "Land Use Change around Protected Areas: Management to Balance Human Needs and Ecological Function”. Ecological Applications, 17(2007): 1031-1038

Defries, Ruth \& Andrew Hansen. "Ecological Mechanisms Linking Protected Areas to Surrounding Lands”. Ecological Applications, 17 (2007): 974-988

De Jode, Helen \& Vanessa Tilstone. Disaster Risk Reduction in the drylands of the Horn of Africa: Good practice examples from the ECHO Drought Cycle Management partners. ed. REGLAP, 2011

Ervin, Jamison. "Protected Area Assessments in Perspective”. BioScience, 53 (2003): 819822

Fairhead, James, Mellisa Leach \& Ian Scoones. "Green Grabbing: a New Appropriation of 
Nature"? The Journal of Peasant Studies, 2(2012) 237-261, doi: 10.1080/03066150.2012.671770.

http://dx.doi.org/10.1080/03066150.2012.671770.

Accesssed: 10 may 2013.

Fratkin, Elliott \& Erick Roth. As Pastoralists Settle: Social, Health and Economic Consequences of Pastoral Sedentarization in Marsabit District Kenya. New York, USA: Kluwer Academic Publishers, 2006.

Fuchs, Vivian Ernest et al. "The Lake Rudolf Rift Valley Expedition". The Geographical Journal 86(1935): 114-137

Granjou, Céline \& Isabelle Mauz. "Gouverner par les Scenarios? Comment les Institutions Gouvernmentales Anticipant l'avenir de la Biodiversité". Quaderni Communication, Technologie, Pouvoir. 76 (2011): 5-12

Hazard, Benoit et al,. Comprehensive Study of Pastoral Livelihoods: WASH and Natural Resource Management in Northern Marsabit. IFRA- solidarities, report, 2012

Herlocker, Dennis J. Vegetation of southwestern Marsabit District, Kenya. UNEP-MAB Integrated Project in Arid Lands. Vol 3, Nairobi: 1979.

Hogg, Richard. "Development in Kenya: Drought, Desertification and Food Scarcity". African Affairs, 86(1987): 47-58

Hubert, Bernard \& Ray Ison. "Institutionalizing Understandings: from Resource Sufficiency to Functional Integrity". In A Paradigm Shift from Livestock Management: from Resource Sufficiency to Functional Integrity. ed. Trish Kammili \& Bernard, Hubert, 9-16. France: Cardere éditeur Lirac, 2011.

Imperato, James \& Eleanor Imperato. They Married Adventure: the Wandering Lives of Martin and Osa Johnson, New Brunswick, New Jersey: Rutgers University Press, 1999.

Joly, Frédéric et al,. "Forage Resource Utilization in Mongolia. Two Concepts Frequently applied in Range Ecology". In A Paradigm Shift from livestock Management: from Resource Sufficiency to Functional Integrity. ed. Trish Kammili \& Bernard Hubert, 57-70. France: Cardere éditeur Lirac, 2011.

Kipkorir, Benjamin \& Joseph Ssennyonga. Socio-Cultural Profile of Marsabit district, Nairobi: Ministry of planning and national development and Institute of African Studies. 2010 .

Lane, Paul. "Trajectories to Pastoralism in Northern and Central Kenya: an Overview of the Archaeological and Environmental Evidence". In Pastoralism in Africa: Past, Present and Future. ed. Michael Bollig \& Hans-Peter Wotzka. 104-144. Oxford: Berghan Books, 2013 
Larrère, Raphael. "La notion de climax", Études rurales, vol 129-130 (1993):15-31. http://etudesrurales.revues.org/1174. Accessed 19 may 2013.

Linton, Jamie. What is Water? The History of a Modern Abstraction. Vancouver: University of British Columbia Press, 2010.

Nyamweru, Celia. "Natural Cultural Sites of Kenya: Changing Contexts, Changing Meanings". Journal of Eastern African Studies, 6 (2012): 270-302.

Robinson, Paul. Gabra Nomadic Pastoralism in Nineteenth and Twentieth Century Northern Kenya: Strategies for Survival in a Marginal Environment, (PhD dissertation, North-western University, 1985).

Rossi, Georges. L'ingérence écologique. Environnement et Développement Rural du Nord au Sud. Paris: CNRS, 1998.

Schlee, Gunther \& Abdullahi Shongolo. Pastoralism and Politics in Northern Kenya \& Southern Ethiopia: James Currey Publishers, 2012.

Selmi, Adel. “L'émergence de l'idée de Parc National en France: De la Protection des Paysages à l'expérimentation Coloniale". In Histoires des Parcs Nationaux. Comment Prendre soin de la Nature?, ed. Raphael Larrère Bernadette Lizet B \& Martine BerlanDarqué, 43-58. Versailles: Quae, 2009.

Warren, Andrew. "Changing Understandings of African Pastoralism and the Nature of Environmental Paradigms". Transactions of the Institute of British Geographers, 20 (1995): 193-203.

Western, David. In the Dust of Kilimanjaro. Washington: Island Press, 2001.

Watkins, Tammy \& Maryam Imbumi. "Forests of Mount Kulal, Kenya: source of water and support to local livelihoods". Food and Agriculture Organization. 58 (2007): 33-37

Witsenburg, Karen \& Wario Roba. Surviving Pastoral Decline: Pastoral Sedentarisation, Natural Resource Management and Livelihood Diversification in Marsabit District, (PhD dissertation, University of Amsterdam, 2004. 